Int. J. Morphol.,

36(3):864-870, 2018.

\title{
Some Indicators of Fatness and Fitness in Kosovian and Montenegro Adolescents
}

\author{
Algunos Indicadores de Obesidad y Estado Físico en Adolescentes de Kosovo y Montenegro
}

\author{
Besnik Morina $^{1}$; Georgi Georgiev ${ }^{2}$ \& Rasid Hadzic ${ }^{3}$
}

MORINA, B.; GEORGIEV, G. \& HADZIC, R. Some indicators of fatness and fitness in Kosovian and Montenegro adolescents. Int. J. Morphol., 36(3):864-870, 2018.

SUMMARY: The aim of the research was to determine the full and age specific differences in obesity and motor abilities by adolescents from two countries in two western Balkan countries in south-eastern Europe: Kosovo and Montenegro. The research was realized on a sample of 1200 respondents. Of these, 600 were from Kosovo and Montenegro, a total of 6 groups from each state (100 respondents in each groups) age (13, 14 and 15 years) and sex (boys and girls). Body height, body weight, body mass index, flamingo balance, plate tapping, sit-and-reach, standing broad jump, handgrip test, sit-ups in 30 seconds, bent arm hang, 10 x 5 meter shuttle run and $20 \mathrm{~m}$ endurance shuttle-run were used in the analysis. The differences in fitness tests, anthropometric measures by Kosovian and Montenegro Adolescents were examined by one-way analysis of covariance. Montenegrin and Kosovo girls and Kosovo boys indicate a smaller overweight and obesity in comparison with peer group from Europe, while boys from Montenegro are placed near to their counterparts from western and southern Europe. Kosovo adolescents of both sexes and Montenegrin male adolescents aged 13 and 14 achieve on average poorer results in the test standing broad jump and 20 meters endurance shuttle-run, but achieving better results of the test pull ups stamina compared to European peers. Montenegrin female adolescents achieve poorer results in the test standing broad jump, but better results of the test pull ups stamina compared to European colleagues.

KEY WORDS: Morphology; Motor skills; Sex.

\section{INTRODUCTION}

Geographical, cultural, and socio-economic factors create a different lifestyle. Today, however, young people's lives in developed countries is mainly characterized by the modern information era. Both television and information technology provide easy and fast way for entertainment and communication for the young people which are important factors in their lifestyles. Many young people live in semi-virtual world of web social networks and very few of them participate in physical activities as they did in the past (Strel et al., 2007; Silva et al., 2010). In connection with some other trends (sheltering praxis of parents, individualisation) sedentary lifestyle is common among young people (Jurak, 2006; Ferreira et al., 2007; Strel, et $a l$.$) . The results from many studies indicate that lifestyle$ changes in developed countries among young people affect the increase of subcutaneous fat (Olds et al., 2007; Strel et al.), a higher proportion of the overweight population (Strauss \& Pollack, 2001; Lobstein \& Frelut, 2003;
Wedderkopp et al., 2004; Malina, 2007; Strel et al.) and decreasing of the fitness level, especially the endurance and strength (Westerståhl et al., 2005; Strel et al.; Tomkinson \& Olds, 2007).

Most commonly, when measuring the diversity in lifestyles between countries, data are associated with differences in dietary habits, access to sports facilities and possibilities for engaging in various physical activities, as well as in differences in education and training systems. Moreover, there are very few studies that examined the cultural and religious differences between two neighboring countries.

Anthropological measures could be an indicator for person's health condition and people's eating habits. Thus, there is a need for studies of anthropological features. Moreover, the results from the anthropological diagnostic

${ }^{1}$ University of Kosovo, Faculty of Physical Education and Sport, Pristina, Kosovo.

${ }^{2}$ Faculty of Physical Education, Sport and Health, University of Skopje, Macedonia.

${ }^{3}$ University of Montenegro, Faculty for Sport and Physical Education, Niksic, Montenegro. 
could be used for prediction of anthropological features such as development, planning, programming and designing quality physical education curricula and programs, identification of talented children, following of body composition and fitness level, preparation of state plans, programs and strategies for promotion of physical activity among the population designated to achieve engaging physical activities for the whole life (Neljak et al., 2012).

Many studies pointed out that the level of anthropological features is affected by different factors, including the following: living environment factors, lifestyle, eating habits (Hebbelinck et al., 1999), cultural differences, and socioeconomic status (Freitas et al., 2007). Therefore, the aim of the research was to identify the differences in some anthropological features among adolescents in Montenegro and Kosovo.

\section{MATERIAL AND METHOD}

Sample of respondents. The research was realized on a sample of 1200 respondents (12 groups). Of these, 600 were from Kosovo and Montenegro, a total of 6 groups from each state (100 respondents in each groups) age (13, 14 and 15 years) and sex (boys and girls).

The participants were treated according to Helsinki Declaration. The measuring was realized in March, April, and May, 2016 in standard school settings on regular classes of health and physical education. The measuring was performed by professionals from the branches of kinesiology and medicine, who were previously trained for measuring certain tests and measures.
Anthropometric measures and Evaluation of Physical Fitness. Data from the Eurofit system (Council of Europe, 1993) were used in the analysis. The data included two morphological andnine motor tests (Table I; additional to Eurofit obstacle course BMI were calculated from body height and body weight). All the tests have suitable measuring characteristics.

Definition of weight status. Three weight status groups were established in this study: normal weight, overweight and obesity. Participants were categorized according to the international sex and age-specific BMI $\left(\mathrm{kg} / \mathrm{m}^{2}\right)$ cut-off points (Cole et al., 2000). These points have been particularly established for children and adolescents aged from 2 to 18 years, separately for males and females and for 0.5 year age groups. These cut off values are based on percentiles passing at age 18 years through BMI $18.5 \mathrm{~kg} / \mathrm{m}^{2}$ for underweight, 25 $\mathrm{kg} / \mathrm{m}^{2}$ for overweight and $30 \mathrm{~kg} / \mathrm{m}^{2}$ for obesity (Cole et al.).

Statistical methods. Regarding the statistical analysis, the characteristics of the sample are presented as mean (standard deviation) or frequencies (percentages) stratified by sex and country. The normal distribution of the applied variables was verifed by the Kolmogorov-Smirnov method. The differences in the anthropometric measures and the fitness tests among Kosovian and Montenegro adolescents have been determined by one-way analysis of covariance (ANCOVA) including age as covariates. Mean differences among rural and urban data and $95 \%$ Confidence Interval (CI) were calculated. Effect size statistics was assessed using Cohen's d (standardized mean differences and $95 \% \mathrm{CI}$ ). Taking into account the cut-off established by Cohen, the effect size can be small ( $\sim 0.2)$, medium $(\sim 0.5)$ or large $(\sim 0.8)$. The significance level was set at $5 \%$ and all calculations were performed using SPSS v. 22.0 software for Windows.

Table I. Sample of variables

\begin{tabular}{lll}
\hline Test & Measured capacity & Measuring unit \\
\hline Body height & Longitudinal dimension of the body & $\mathrm{cm}$ \\
Body weight & Volume of the body & $\mathrm{kg}$ \\
BMI & Body mass index & $\mathrm{kg} / \mathrm{m}^{2}$ \\
Flamingo balance & to assess the ability to balance succes sfully on a single leg. & no. of repetitions \\
Plate Tapping & tests speed of limb movement & $\mathrm{seconds}$ \\
Sit-and-Reach & flexibility test (using 15cm at the level of the feet) & $\mathrm{cm}$ \\
Standing Broad Jump & measures explosive leg power. & $\mathrm{cm}$ \\
Handgrip Test & measures static arm strength & $\mathrm{kg}$ \\
Sit-Ups in 30 seconds & measures trunk strength & $\mathrm{no}$. of repetitions \\
Bent Arm Hang & muscular enduranc e/functional strength & $\mathrm{seconds}$ \\
$10 \mathrm{x} 5$ meter Shuttle Run & measures running speed and agility & $\mathrm{seconds}$ \\
$20 \mathrm{~m}$ endurance shuttle-run & cardiorespiratory endurance & $\mathrm{km} / \mathrm{h}$ \\
\hline
\end{tabular}




\section{RESULTS}

Table II shows the data of the anthropometric and physical fitness variables in relation to the place of residence of the male respondents. Descriptive data, mean differences, effect size and $95 \% \mathrm{CI}$ are presented. The ANCOVA analyses showed that Kosovo adolescent have lower height ( $\mathrm{p}=0,004$; mean difference $=2,01 \mathrm{~cm}$; Cohen's $\mathrm{d}=0,20$ ) and body mass $(\mathrm{p}=0,003$; mean difference $=2.96 \mathrm{~kg}$; Cohen's $\mathrm{d}=0,22)$ than their Montenegro peers. Kosovo male adolescents indicate better results in fitness tests flamingo balance, $(\mathrm{p}=0,015$; mean difference $=1.22$; Cohen's $\mathrm{d}=0.20$ ) plate tapping $(\mathrm{p}<0.001$; mean difference $=.598$; Cohen's $d=0.33)$, Standing Broad Jump ( $<<0.001$; mean difference $=10.33$; Cohen's $\mathrm{d}=0.37)$ and $10 \times 5$ meter Shuttle Run $(\mathrm{p}<0.001$; mean difference $=1.25$; Cohen's $d=0.61)$. Montenegrin male adolescents indicate better results only in the Sit-Ups in 30 seconds ( $\mathrm{p}=0.010$; mean difference $=.820$; Cohen's $\mathrm{d}=0.21$ ). In other fitness tests, statistically significant differences between male and female adolescents from Kosovo and Montenegro have not been determined.

Table III shows data of the anthropometric and physical fitness variables among female adolescents in Montenegro and Kosovo. Montenegrin female adolescents are higher $(\mathrm{p}<0.001$; mean difference $=2.25$; Cohen's $\mathrm{d}=0.34$ ) and heavier $(\mathrm{p}=0.016$; mean difference $=2.02$; Cohen's $\mathrm{d}=0.19$ ), and show better results in the fitness test Sit-Ups in 30 seconds ( $\mathrm{p}<0.001$; mean difference $=2.55$; Cohen's $\mathrm{d}=0.53)$ and $20 \mathrm{~m}$ endurance shuttle-run $(\mathrm{p}=0.013$; mean

Table II. Anthropometric and physical fitness indicators in Kosovo and Montenegro adolescents (Boys).

\begin{tabular}{|c|c|c|c|c|c|c|c|c|c|c|c|}
\hline \multirow{3}{*}{ Body height } & \multicolumn{2}{|c|}{ Kosovo } & \multicolumn{2}{|c|}{ Montenegro } & \multicolumn{4}{|c|}{ Mean differences } & \multicolumn{3}{|c|}{ Effect size } \\
\hline & \multirow{2}{*}{$\begin{array}{l}\text { Mean } \\
54.79\end{array}$} & \multirow{2}{*}{$\begin{array}{c}\text { SE } \\
0.71\end{array}$} & \multirow{2}{*}{$\begin{array}{l}\text { Mean } \\
57.76\end{array}$} & \multirow{2}{*}{$\begin{array}{r}\text { SE } \\
0.71\end{array}$} & \multirow{2}{*}{$\frac{\text { Mean }}{-2.96^{*}}$} & \multirow{2}{*}{$\begin{array}{c}\text { SE } \\
1.00\end{array}$} & \multicolumn{2}{|c|}{$95 \% \mathrm{CI}$} & \multirow{2}{*}{$\begin{array}{l}C^{\prime} d \\
-0.22\end{array}$} & \multicolumn{2}{|c|}{$95 \% \mathrm{CI}$} \\
\hline & & & & & & & -4.94 & -0.99 & & -1.64 & 1.35 \\
\hline Body weight & 165.14 & 0.49 & 167.15 & 0.49 & $-2.01 *$ & 0.70 & -3.38 & -0.64 & -0.20 & -1.27 & 0.96 \\
\hline BMI & 19.94 & 0.20 & 20.45 & 0.20 & -0.51 & 0.29 & -1.07 & 0.05 & -0.14 & -0.55 & 0.25 \\
\hline Flamingo balance & 13.62 & 0.35 & 12.41 & 0.35 & $1.22 *$ & 0.50 & 0.24 & 2.20 & 0.20 & -0.57 & 0.81 \\
\hline Plate Tapping & 10.08 & 0.10 & 10.68 & 0.10 & $-.598^{*}$ & 0.14 & -0.88 & -0.32 & -0.33 & -0.49 & -0.10 \\
\hline Sit-and-Reach & 24.71 & 0.44 & 25.54 & 0.44 & -0.83 & 0.62 & -2.05 & 0.40 & -0.11 & -0.98 & 0.77 \\
\hline Standing Jump & 167.81 & 1.55 & 157.46 & 1.55 & $10.33^{*}$ & 2.20 & 6.04 & 14.67 & 0.37 & -2.93 & 3.44 \\
\hline Handgrip Test (D) & 31.26 & 0.44 & 31.24 & 0.44 & 0.02 & 0.63 & -1.21 & 1.25 & 0.00 & -1.01 & 0.96 \\
\hline Handgrip Test (L) & 28.52 & 0.41 & 29.33 & 0.41 & -0.81 & 0.58 & -1.95 & 0.34 & -0.10 & -0.99 & 0.83 \\
\hline Sit-Ups in $30 \mathrm{~s}$. & 18.45 & 0.23 & 19.27 & 0.23 & $-.820^{*}$ & 0.32 & -1.45 & -0.20 & -0.21 & -0.63 & 0.26 \\
\hline Bent Arm Hang & 27.53 & 1.28 & 27.89 & 1.28 & -0.36 & 1.81 & -3.91 & 3.19 & -0.02 & -2.59 & 2.46 \\
\hline $10 \times 5 \mathrm{~m}$. shuttle-run & 19.32 & 0.12 & 20.57 & 0.12 & $-1.25 *$ & 0.17 & -1.57 & -0.92 & -0.61 & -0.77 & -0.33 \\
\hline $20 \mathrm{~m}$ shuttle-run & 5.32 & 0.10 & 5.48 & 0.10 & -0.16 & 0.15 & -0.45 & 0.13 & -0.09 & -0.30 & 0.11 \\
\hline
\end{tabular}

Table III. Anthropometric and physical fitness indicators in Kosovo and Montenegro adolescents (Girls).

\begin{tabular}{|c|c|c|c|c|c|c|c|c|c|c|c|}
\hline \multirow[b]{3}{*}{ Body height } & \multicolumn{2}{|c|}{ Kosovo } & \multicolumn{2}{|c|}{ Montenegro } & \multicolumn{2}{|c|}{ Mean differences } & \multicolumn{5}{|c|}{ Effect size } \\
\hline & \multirow{2}{*}{$\begin{array}{l}\text { Mean } \\
51.92\end{array}$} & \multirow{2}{*}{$\begin{array}{c}\text { SE } \\
0.59\end{array}$} & \multirow{2}{*}{$\begin{array}{l}\text { Mean } \\
53.94\end{array}$} & \multirow{2}{*}{$\begin{array}{r}\mathrm{SE} \\
0.59\end{array}$} & \multirow{2}{*}{$\begin{array}{r}\text { Mean } \\
-2.02^{*}\end{array}$} & \multirow{2}{*}{$\begin{array}{r}\mathrm{SE} \\
0.83\end{array}$} & \multicolumn{2}{|c|}{$95 \% \mathrm{CI}$} & \multirow{2}{*}{$\begin{array}{l}C^{\prime} d \\
-0.19\end{array}$} & \multicolumn{2}{|c|}{$95 \% \mathrm{CI}$} \\
\hline & & & & & & & -3.65 & -0.38 & & -1.39 & 1.01 \\
\hline Body weight & 160.68 & 0.37 & 162.93 & 0.37 & $-2.25^{*}$ & 0.53 & -3.28 & -1.22 & -0.34 & -1.09 & 0.42 \\
\hline BMI & 20.03 & 0.19 & 20.24 & 0.19 & -0.21 & 0.27 & -0.74 & 0.32 & -0.06 & -0.45 & 0.32 \\
\hline Flamingo balance & 13.58 & 0.33 & 12.92 & 0.33 & 0.66 & 0.46 & -0.25 & 1.57 & 0.12 & -0.54 & 0.74 \\
\hline Plate Tapping & 10.35 & 0.08 & 10.43 & 0.08 & -0.08 & 0.12 & -0.32 & 0.15 & -0.06 & -0.21 & 0.12 \\
\hline Sit-and-Reach & 30.67 & 0.44 & 29.65 & 0.44 & 1.02 & 0.62 & -0.19 & 2.24 & 0.13 & -0.79 & 0.94 \\
\hline Standing Jump & 137.96 & 1.24 & 136.72 & 1.24 & 1.24 & 1.75 & -2.19 & 4.67 & 0.06 & -2.26 & 2.57 \\
\hline Handgrip Test (D) & 26.41 & 0.30 & 25.78 & 0.30 & 0.63 & 0.42 & -0.20 & 1.46 & 0.12 & -0.49 & 0.74 \\
\hline Handgrip Test (L) & 24.74 & 0.29 & 24.26 & 0.29 & 0.48 & 0.41 & -0.33 & 1.28 & 0.09 & -0.49 & 0.69 \\
\hline Sit-Ups in $30 \mathrm{~s}$. & 12.91 & 0.28 & 15.45 & 0.28 & $-2.55^{*}$ & 0.40 & -3.32 & -1.77 & -0.53 & -1.11 & -0.01 \\
\hline Bent Arm Hang & 12.57 & 0.74 & 13.63 & 0.74 & -1.07 & 1.05 & -3.14 & 1.00 & -0.08 & -1.49 & 1.43 \\
\hline $10 \times 5 \mathrm{~m}$. shuttle-run & 21.49 & 0.12 & 22.36 & 0.12 & $-.873 *$ & 0.17 & -1.20 & -0.54 & -0.42 & -0.62 & -0.15 \\
\hline $20 \mathrm{~m}$ shuttle-run & 3.78 & 0.07 & 4.02 & 0.07 & $-.236^{*}$ & 0.10 & -0.42 & -0.05 & -0.20 & -0.32 & -0.06 \\
\hline
\end{tabular}

Analyses were adjusted by age. Values are adjusted means (SE, standard errors of the means). Mean differences (Kosovo - Montenegro ) are expressed as mean (SE) and $95 \%$ Confidence interval. Effect size statistics are expressed as Cohen's d (C'd) and $95 \%$ Confidence interval. Therewas no missing data for the variables shown $(\mathrm{n}=600)$. 
difference $=.837$; Cohen's d=0.42). Kosovo female adolescents show better results in the test 10x5 meter Shuttle Run ( $\mathrm{p}<0.001$; mean difference $=.236$; Cohen's d=0.20). In other fitness tests, statistically significant differences between male and female adolescents from Kosovo and Montenegro have not been determined.

A large percentage of Montenegrin boys are overweight and obese in comparison to boys from Kosovo (Table IV). The percentage of Montenegrin 13 and 15 years old girls with overweight and obesity is greater (Montenegro - 19,0 \%; Kosovo - 17,0 \%) compared to the Kosovo girls (Montenegro - 11,0 \%; Kosovo - 6,0 \%). By 13 years old girls in both countries there is a $15 \%$ overweight and obesity. At the level of the whole sample there are statistically significant differences in the degree of malnutrition among boys from Montenegro and Kosovo - Table V ( $22=10.02$; $\mathrm{p}=.007)$. Percentage values show that a larger percentage of boys aged 13 to 15 years old from Montenegro are overweight and obese (Montenegro - 25,40 \%; Kosovo - 16,00\%). Statistically significant differences were also found in the degree of malnutrition among girls aged 13 to 15 years from Montenegro and Kosovo - Table VI (c2=6.34; p=.042). Percentage values show that a greater percentage of girls in Montenegro are overweight and obese (Montenegro - 17.30 $\%$ and Kosovo - $10.70 \%$ ).

Table IV. Prevalence of normal, overweight and obese adolescent.

\begin{tabular}{|c|c|c|c|c|c|c|c|c|c|c|c|c|}
\hline \multirow[b]{3}{*}{ Age } & \multicolumn{6}{|c|}{ Kosovo } & \multicolumn{6}{|c|}{ Montenegro } \\
\hline & \multicolumn{3}{|c|}{ Boys } & \multicolumn{3}{|c|}{ Girls } & \multicolumn{3}{|c|}{ Boys } & \multicolumn{3}{|c|}{ Girls } \\
\hline & $\mathrm{N}$ & OW & OB & $\mathrm{N}$ & OW & $\mathrm{OB}$ & $\mathrm{N}$ & OW & $\mathrm{OB}$ & $\mathrm{N}$ & OW & $\mathrm{OB}$ \\
\hline 13 years & 87.0 & 11.0 & 2.0 & 89.0 & 5.0 & 6.0 & 74.0 & 21.0 & 5.0 & 81.0 & 13.0 & 6.0 \\
\hline 14 years & 81.0 & 12.0 & 7.0 & 85.0 & 11.0 & 4.0 & 77.0 & 21.0 & 2.0 & 84.0 & 15.0 & 1.0 \\
\hline 15 years & 84.0 & 13.0 & 3.0 & 94.0 & 5.0 & 1.0 & 73.0 & 23.0 & 4.0 & 83.0 & 11.0 & 6.0 \\
\hline
\end{tabular}

$\mathrm{N}=$ Normal weight, $\mathrm{OW}=$ Overweight, $\mathrm{OB}=$ Obese.

Table V. Prevalence of normal, overweight and obese adolescent (Boys).

\begin{tabular}{lllllll}
\hline & & $\mathrm{N}$ & \multicolumn{2}{l}{ OW } & \multicolumn{2}{c}{ OB } \\
\hline Kosovo & 252 & $84.00 \%$ & 36 & $12.00 \%$ & 12 & $4.00 \%$ \\
Montenegro & 224 & $74.70 \%$ & 65 & $21.70 \%$ & 11 & $3.70 \%$ \\
\hline
\end{tabular}

$\mathrm{c}^{2}=10.02 ; \mathrm{P}=.007$

Table VI. Prevalence of normal, overweight and obese adolescent (Girls).

\begin{tabular}{llrrrrr}
\hline & \multicolumn{2}{c}{$\mathrm{N}$} & \multicolumn{2}{c}{$\mathrm{OW}$} & \multicolumn{2}{c}{ OB } \\
\hline Kosovo & 268 & $89.30 \%$ & 21 & $7.00 \%$ & 11 & $3.70 \%$ \\
Montenegro & 248 & $82.70 \%$ & 39 & $13.00 \%$ & 13 & $4.30 \%$ \\
\hline $\mathrm{c}^{2}=6.34 ; \mathrm{P}=.042$ & & & & & &
\end{tabular}

\section{DISCUSSION}

A number of recent researches show that the environmental factors (European Commission/EACEA/ Eurydice, 2013), cultural differences (Prskalo et al., 2011), social and economic conditions (Jiménez-Pavón et al., 2010,b), differences in curricula and programs in physical education, as well as the number, proximity and access to sports objects, significanlty affect the fitness level and physical activity among children and adolescents. With this in mind, the purpose of this research was to determine whether there were differences in fitness levels among adolescents from Kosovo and Montenegro aged 13 to 15 years old. The results of the survey show that adolescents from Montenegro statistically significantly differ from the sample of adolescents from Kosovo in a number of investigated variables. Kosovo male adolescents show better results in fitness tests Flamingo balance, Plate Tapping, Standing Broad Jump and 10 x 5 m Shuttle Run. Montenegrin male adolescents are heavier and taller, showing better results 
in the Sit-Ups test in 30 seconds. Montenegrin female adolescents are taller and heavier and show better results in fitness sit-ups tests in 30 seconds and $20 \mathrm{~m}$ endurance shuttlerun. Kosovo female adolescents show better results in the 10x5 meter Shuttle Run test. However, all fitness tests show small mean differences and small to medium effects among Kosovo and Montenegro participants, which can explain a large percentage of variance in fitness (e.g. genetics).

Little is known about the geographic variability in children's physical fitness performances and the reasons that determine the differences. Countries from ex-Yugoslavia are located in central and south-eastern Europe. Therefore, it can be expected lower prevalence of overweight and obesity and superior physical fitness performance of Kosovian and Montenegro adolescent would therefore be expected according to previously found gradient of prevalence of overweight and obesity in Europe (Wijnhoven et al., 2013; Jurak et al., 2015) and fitness performance levels (Wijnhoven et al.). However, the results of our research did not confirm these assumptions.

Differences in morphological characteristics can be one of the reasons for the differences in a number of fitness tests. The results of the survey showed that Montenegrin male and female adolescents are higher and heavier than Kosovo adolescents. This is not so unusual since the data about the influence of those characteristics on the performance of motor tests are contradictory. Body mass was found to be negatively connected with body movement (especially running capacity) in several studies (Wedderkopp et al.; Strel et al.; Tomkinson \& Olds), yet the data about the influence of body height on motor tests performance are contradictory.

Some other factors, could have also contributed to the differences in motor fitness among Kosovian and Montenegro adolescent. As mentioned above, there is a possibility that the genetics, geographical environment and different eating habits (Strauss \& Polack) play a key role for the differences in morphological characteristics and fitness abilities. Although previous researches did not provide a final answer of these questions, a greater number of studies show that social and economic conditions in which the individual lives and the ecosystem are related to the level of fitness abilities, as well as some morphological characteristics (Jumenes Pavon et al., 2010a and 2010b). According to the research of Jimenes et al. (2010b), higher socioeconomic status is in negative ratio with the BMI; in other terms, in more developed countries with better socioeconomic status, there is a lower prevalence of obesity.

Determined differences in motoric abilities among adolescents from Montenegro and Kosovo could be due to the differences in curricula and programs in physical education and different settings for teaching. According to European Commission, there are differences in curricula and programs in European countries. About a third of educational systems in Europe have two levels of teaching for physical education: obligatory and optional program (European Commission/EACEA/Eurydice).

Comparing the overweight and obesity prevalence of our study with international studies to date (Wijnhoven et al.), it can be concluded that Montenegrin, Kosovo girls and Kosovo boys show lower overweight and obesity over peers in Europe, while boys from Montenegro are placed near to their counterparts from western and southern Europe. Our key finding about differences in the prevalence of overweight and obesity among Kosovo and Montenegro adolescents is that sex is a more significant classifying predictor in BMI group than nationality. The prevalence of overweight and obesity in both Montenegro and Kosovo is greater in boys. This conclusion is confirmed in a number of European countries (Wijnhoven et al.; Gontarev \& Kalac, 2014; Jurak et al.). Several studies indicate that obese and overweight children had the greatest risk of becoming obese or overweight young adults (Starc \& Strel, 2011). Therefore, the monitoring of obesity during childhood and adolescence is an important issue.

Kosovo adolescents of both sexes and Montenegrin male adolescents aged 13 and 14 achieve on average poorer results in the test jump in distance from place and $20 \mathrm{~m}$ endurance shuttle-run, significantly better results in the test pull ups stamina compared to European peers measured in the HELENA study (Ortega et al., 2011). Montenegrin female adolescents achieve poorer results in the test jump in distance from place, and better results in the test pull ups stamina compared to the European female adolescents of the same age measured in the HELENA study.

According to the gained results, future studies should examine the genetics, living environment, geographic region, cultural specifics, socioeconomic status, different eating habits, as well as the impact of different curricula for physical education on motoric abilities.

In order to facilitate the comparison between various countries, as well as easier following of the trends, a continuous observation of fitness level and physical activity is needed, both on global and national level, as well as assimilation of methodology for assessment of physical activity and fitness level. High prevalence of physical inactivity among children and adolescents requires preparation of state strategies for change of the habits for physical activity. 


\section{CONCLUSION}

This study gains knowledge about the level and variability of the fatness and motor fitness of children in the western Balkan region in south-east Europe. Prevalence of overweight and obesity of Kosovian and Montenegro Adolescent compared to their counterparts across Europe vary by sex. Montenegrin and Kosovo girls and Kosovo boys show a smaller overweight and obesity over age peers from Europe, while boys from Montenegro are placed near to their counterparts from western and southern Europe. Kosovo adolescents of both sexes and Montenegrin male adolescents aged 13 and 14 achieve on average poorer results in the test jump in distance from place and $20 \mathrm{~m}$ endurance shuttlerun, better results in the test pull ups stamina compared to European peers. Montenegrin female adolescents achieve poorer results in the test jump in distance from place and better results in the test pull ups stamina compared to European colleagues.

According to the results obtained in future studies more morphological and motor variables should be included. In addition, the impact of some factors of the socio-cultural environment should be explored, such as standards in PE teaching (number of students per teacher, access to sports halls with quality sports equipment), competences in PE teaching (PE teachers and class teachers), the extracurricular sport activity of young people and environmental conditions (availability and access to sports facilities), which could explain differences in of fatness and fitness.

MORINA, B.; GEORGIEV, G. \& HADZIC, R. Algunos indicadores de obesidad y estado físico en adolescentes de Kosovo y Montenegro. Int. J. Morphol., 36(3):864-870, 2018.

RESUMEN: El objetivo de la investigación fue determinar las diferencias completas y específicas por edad en la obesidad y las habilidades motoras de adolescentes de dos países de los Balcanes Occidentales en el sudeste de Europa: Kosovo y Montenegro. La investigación se realizó en una muestra de 1200 encuestados. De ellos, 600 eran de Kosovo y Montenegro, un total de 6 grupos de cada estado (100 encuestados en cada grupo) de edades ( 13,14 y 15 años) y sexo (niños y niñas). Se midió la altura del cuerpo, peso corporal, índice de masa corporal, equilibrio de flamencos, golpeteo de placa, sentado y alcance, salto de pie, prueba de agarre, abdominales en 30 segundos, colgar brazo flexionado, carrera de lanzadera de 10 x 5 metros y resistencia de $20 \mathrm{~m}$ shuttlerun. Las diferencias en las pruebas de aptitud, medidas antropométricas en adolescentes de Kosovo y Montenegro fueron examinadas a través de análisis unidireccional de covarianza. Las niñas montenegrinas y kosovares y los niños de Kosovo tenían menor sobrepeso y obesidad en comparación con el grupo de sus pares europeos, mientras que los niños de Montenegro están ubi- cados cerca de sus homólogos de Europa occidental y meridional. Los adolescentes de Kosovo de ambos sexos y los adolescentes montenegrinos de 13 y 14 años obtuvieron en promedio resultados más pobres en la prueba de salto de ancho y 20 metros de resistencia, pero lograron mejores resultados de resistencia en las pruebas en comparación con sus pares europeos. Las adolescentes montenegrinas lograron resultados más pobres en la prueba de salto de pie, pero mejores resultados de la prueba aumentan la resistencia en comparación con los pares europeos.

PALABRAS CLAVE: Morfología; Habilidades motoras; Sexo.

\section{REFERENCES}

Cole, T. J.; Bellizzi, M. C.; Flegal, K. M. \& Dietz, W. H. Establishing a standard definition for child overweight and obesity worldwide: international survey. B. M. J., 320(7244):1240-3, 2000.

European Commission/EACEA/Eurydice. Physical Education and Sport at School in Europe Eurydice Report. Luxembourg, Publications Office of the European Union, 2013.

Ferreira, I.; van der Horst, K.; Wendel-Vos, W.; Kremers, S.; van Lenthe, F. J. \& Brug, J. Environmental correlates of physical activity in youth - a review and update. Obes. Rev., 8(2):129-54, 2007.

Freitas, D. L.; Maia, J.; Beunen, G.; Claessens, A.; Thomis, M.; Marques, A.; Crespo, M. \& Lefevre, J. Socio-economic status, growth, physical activity and fitness: the Madeira Growth Study. Ann. Hum. Biol., 34(1):107-22, 2007.

Gontarev, S. \& Kalac, R. Association between obesity and socioeconomic factors in Macedonian children and adolescents. Adv. Life Sci. Health, 1(1):55-63, 2014.

Hebbelinck, M.; Clarys, P. \& De Malsche, A. Growth, development, and physical fitness of Flemish vegetarian children, adolescents, and young adults. Am. J. Clin. Nutr., 70(3 Suppl.):579S-85S, 1999.

Jiménez-Pavón, D.; Ortega, F. B.; Ruiz, J. R.; Chillón, P.; Castillo, R.; Artero, E. G.; Martinez-Gómez, D.; Vicente-Rodriguez, G.; Rey-López, J. P.; Gracia, L. A.; Noriega, M. J.; Moreno, L. A. \& Gonzalez-Gross, M. Influence of socioeconomic factors on fitness and fatness in Spanish adolescents: the AVENA study. Int. J. Pediatr. Obes., 5(6):467-73, 2010 a.

Jiménez-Pavón, D.; Ortega, F. P.; Ruiz, J. R.; España Romero, V.; García Artero, E.; Moliner Urdiales, D.; Gómez Martínez, S.; Vicente Rodríguez, G.; Manios, Y.; Béghin, L.; Répasy, J.; Sjöstrom, M.; Moreno, L. A.; González Gross, M.; Castillo, M. J. \& HELENA Study Group. Socioeconomic status influences physical fitness in European adolescents independently of body fat and physical activity: the HELENA study. Nutr. Hosp., 25(2):311-6, 2010b.

Jurak, G. Sporting lifestyle vs. 'cigarettes \& coffee' lifestyle of Slovenian high school students. Anthropol. Noteb., 12(2):79-95, 2006.

Jurak, G.; Milanovic, I.; Janic, S. R.; Soric, M. \& Kovac, M. Some Indicators of fatness and motor fitness in slovenian and Serbian children. Int. J. Morphol., 33(2):420-7, 2015.

Lobstein, T. \& Frelut, M. L. Prevalence of overweight among children in Europe. Obes. Rev., 4(4):195-200, 2003.

Malina, R. M. Physical fitness of children and adolescents in the United States: status and secular change. Med. Sport Sci., 50:67-90, 2007.

Neljak, B.; Novak, D.; Sporis, G.; Viskovic, S. \& Markus, D. Metodologija vrednovanja kinantropoloskih obiljezja ucenika u tjelesnoj $i$ zdravstvenoj kulturi. Crofit norme. Zagreb, Kinezioloski fakultet, 2012.

Olds, T. S.; Ridley, K. \& Tomkinson, G. R. declines in aerobic fitness: are they only due to increasing fatness? Med. Sport Sci., 50:226-40, 2007. 
Ortega, F. B.; Artero, E. G.; Ruiz, J. R.; España-Romero, V.; Jiménez-Pavón, D.; Vicente-Rodriguez, G.; Moreno, L. A.; Manios, Y.; Béghin, L.; Ottevaere, C.; Ciarapica, D.; Sarri, K.; Dietrich, S.; Blair, S. N.; Kersting, M.; Molnar, D.; González-Gross, M.; Gutiérrez, A.; Sjöström, M.; Castillo, M. J. \& HELENA study. Physical fitness levels among European adolescents: the HELENA study. Br. J. Sports Med., 45(1):209, 2011.

Prskalo, I.; Kraljevic, Z. \& Kovacic, M. Mjesto stanovanja prediktor spolnog dimorfizma nekih motorickih sposobnosti u primarnoj edukaciji. In: Prskalo, I. \& Novak, D. (Eds.). Proceedings Book of 6th FIEP European Congress. Porec, FIEP European Congress, 2011, pp.394-9.

Silva, P.; Sousa, M.; Seabra, L. A. A.; Ribeiro, J.; Welk, G. \& Mota, J. Physical activity patterns in Portuguese adolescents: The contribution of extracurricular sports. Eur. Phys. Educ. Rev., 16(2):171-81, 2010.

Starc, G. \& Strel, J. Tracking excess weight and obesity from childhood to young adulthood: a 12-year prospective cohort study in Slovenia. Public Health Nutr., 14(1):49-55, 2011.

Strauss, R. S. \& Pollack, H. A. Epidemic increase in childhood overweight, 1986-1998. JAMA, 286(22):2845-8, 2001.

Strel, J.; Kovac, M. \& Jurak, G. Physical and Motor Development, Sport Activities and Lifestyles of Slovenian Children and Youth-Changes in the Last Few Decades. In: Brettschneider, W. D. \& Naul, R. (Eds.). Obesity in Europe: Young People's Physical Activity and Sedentary Lifestyles. Frankfurt, Peter Lang, 2007. pp.243-64.

Tomkinson, G. R. \& Olds, T. S. Secular changes in pediatric aerobic fitness test performance: the global picture. Med. Sport Sci., 50:46-66, 2007.

Wedderkopp, N.; Froberg, K.; Hansen, H. S. \& Andersen, L. B. Secular trends in physical fitness and obesity in Danish 9-year-old girls and boys: Odense School Child Study and Danish substudy of the European Youth Heart Study. Scand. J. Med. Sci. Sports, 14(3):150-5, 2004.

Westerståhl, M.; Barnekow-Bergkvist, M. \& Jansson, E. Low physical activity among adolescents in practical education. Scand. J. Med. Sci. Sports, 15(5):287-97, 2005.

Wijnhoven, T. M.; van Raaij, J. M.; Spinelli, A.; Rito, A. I.; Hovengen, R.; Kunesova, M.; Starc, G.; Rutter, H.; Sjöberg, A.; Petrauskiene, A.; O'Dwyer, U.; Petrova, S.; Farrugia Sant'angelo, V.; Wauters, M.; Yngve, A.; Rubana, I. M. \& Breda, J. WHO European Childhood Obesity Surveillance Initiative 2008: weight, height and body mass index in 69-year-old children. Pediatr. Obes., 8(2):79-97, 2013.

Corresponding author:
Mr. SCI Besnik Morina

University of Pristina,

Faculty of Physical Education and Sport

Pristina

KOSOVO

Email: besnik.morina@uni-pr.edu

Received: 26-01-2018

Accepted: 08-05-2018 